\title{
A Rare Intracerebral Collateral Circulation Pathway from the Contralateral Vertebral Artery to the Ipsilateral Posterior Inferior Cerebellar Artery-V4 Segment Steal
}

\section{Yang Liu}

Qiqihar Medical University

\section{Bian Yang}

Sixth Medical Center of PLA General Hospital https://orcid.org/0000-0002-4002-5646

Jianan Wang

General Hospital of the PLA Rocket Force

Xiongwei Zhang

General Hospital of the PLA Rocket Force

\section{Yan Miao}

Sixth Medical Center of PLA General Hospital

\section{Kunyu Wang}

Sixth Medical Center of PLA General Hospital

Chunyan Li

Qiqihar Medical University

Feng Qiu ( $\nabla$ qiufengnet@hotmail.com )

\section{Research article}

Keywords: Vertebral artery, Occlusive disease, Posterior Inferior cerebellar artery, Steal blood, Collateral circulation

Posted Date: May 26th, 2020

DOI: https://doi.org/10.21203/rs.3.rs-25705/v1

License: @ (i) This work is licensed under a Creative Commons Attribution 4.0 International License. Read Full License 


\section{Abstract}

Background: Interrupted blood flow during ischemia can be compensated through collateral circulation when a cerebral artery is severely stenotic or occluded. We suppose that potential collateral pathway may exist in patients with vertebral artery occlusive disease (VAOD) around V4 segment due to the ipsilateral posterior inferior cerebellar artery (PICA) is sometimes patented after VAOD in the V4 segment.

Methods: We retrospectively examined the medical database of 60 patients with VAOD admitted to the Department of Neurology from the Sixth medical center of the Chinese People's Liberation Army General Hospital and the Second Affiliated Hospital of Qiqihar Medical University from June 2018 to November 2019. The pathways which supplied PICA were investigated by digital subtraction angiography (DSA).

Results: 18 patients were proximal to the exit point of the PICA among all 60 patients with VAOD in V4 segment cases, and 7 individuals $(11.7 \%)$ had the collateral circulation pathway via the contralateral vertebral artery $(\mathrm{VA}){ }^{\circledR}$ vertebrobasilar junction $\AA^{\circledR}$ ipsilateral VA $\AA$ ipsilateral PICA in the DSA.

Conclusions: There is an underestimated intracerebral collateral circulation pathway when VAOD from the contralateral VA to the Ipsilateral PICA, we name this phenomenon "V4 segment steal."

\section{Background}

Interrupted blood flow during ischemia can be compensated through collateral circulation when a cerebral artery is severely stenotic or occluded $(1,2)$. Intracerebral vascular steal is now considered as a paradoxical vasodilatory response by reducing cerebral blood flow to adjacent impaired perfusion area. Intracerebral vascular steal is now considered as a paradoxical vasodilatory response by reducing cerebral blood flow to adjacent impaired perfusion area. Arterial steal develops when a) blood pressure in the ipsilateral artery decreases substantially, creating gradients from high to low pressure systems, and b) adequate arterial or arteriolar anastomoses are present (3).Collateral circulation of cerebral arteries and cerebral blood steal are closely related to the occurrence, development and prognosis of ischemic stroke (4-6). Previous studies have indicated that the most common arterial steal pathways are subclavian artery steal (7) and carotid artery steal (8-10). We suppose that potential intracerebral collateral circulation pathway may exist in patients with vertebral artery occlusive disease (VAOD) around V4 intracranial segment due to the ipsilateral posterior inferior cerebellar artery (PICA) is sometimes patented after VAOD in the V4 segment.

\section{Methods}

We retrospectively examined the medical database for patients admitted to the Department of Neurology from the Sixth medical center of the Chinese People's Liberation Army (PLA) General Hospital and the Second Affiliated Hospital of Qiqihar Medical University from June 2018 to November 2019. From the 
database we found 60 patients with vertebral artery occlusive disease (VAOD) in the V4 segment that met the criteria for severe stenosis or occlusion of cerebral artery developed by the North American Symptomatic Carotid Endarterectomy (NASCET) cooperation group (11). We summarized their examination results and images. Digital subtraction angiography (DSA) offered dynamic images of vertebral artery intracranial and extracranial arteries and collateral circulation. Magnetic resonance imaging (MRI) with the diffusion-weighted imaging (DWI) sequence detected if there were new onset PICA territory infarcts, which met the criteria of New England Medical Center's Posterior Circulation Stroke Registry.

\section{Results}

Among the 60 VAOD in V4 segment cases, 18 were proximal to the exit point of the posterior inferior cerebellar artery (PICA), and in seven (11.7\%) we could observe the collateral circulation pathway via the contralateral VA $\rightarrow$ vertebrobasilar junction $\rightarrow$ ipsilateral VA $\rightarrow$ ipsilateral PICA in the DSA (Fig. 1, 2).

All seven cases were males. Their mean $( \pm S D)$ age was $60.3( \pm 9.7)$ years. They all characterized by dizziness and other symptoms of posterior cerebellar circulation ischemia (Table 1). DWIs from MRIs suggested a new cerebral infarction in five cases, two of which led to contralateral posterior circulation cerebral infarction, and one of which was directly related to the blood supply area of the PICA on the affected side (12). 
Table 1

The summary of clinical data for the 7 patients of "V4 segment steal"

\begin{tabular}{|c|c|c|c|c|c|c|}
\hline No. & $\begin{array}{l}\text { Age } \\
\text { ranges }\end{array}$ & gender & phenotype & $\begin{array}{l}\text { infarction } \\
\text { distribution }\end{array}$ & offending vessels & $\begin{array}{l}\text { PICA } \\
\text { steal (or } \\
\text { V4 } \\
\text { segment } \\
\text { steal) } \\
\text { syntrome }\end{array}$ \\
\hline 1 & $<60$ & male & $\begin{array}{l}\text { intermittent } \\
\text { dizziness }\end{array}$ & No & $\begin{array}{l}\text { occlusion of the left vertebral } \\
\text { artery V1 segment, LVA V4 } \\
\text { proximal, left internal carotid } \\
\text { artery, right middle cerebral } \\
\text { artery }\end{array}$ & No \\
\hline 2 & $\geq 60$ & male & $\begin{array}{l}\text { intermittent } \\
\text { dizziness }\end{array}$ & No & $\begin{array}{l}\text { severe stenosis of the right } \\
\text { vertebral artery } \mathrm{V} 1-\mathrm{V} 4 \\
\text { proximal and the basilar artery }\end{array}$ & No \\
\hline 3 & $<60$ & male & dizziness & $\begin{array}{l}\text { right } \\
\text { cerebellum }\end{array}$ & $\begin{array}{l}\text { occlusion of the right vertebral } \\
\text { artery v1-v4 }\end{array}$ & No \\
\hline 4 & $\geq 60$ & male & $\begin{array}{l}\text { Paroxysmal } \\
\text { left } \\
\text { amaurosis, } \\
\text { cirop attack }\end{array}$ & $\begin{array}{l}\text { bilateral } \\
\text { frontal } \\
\text { lobe }\end{array}$ & $\begin{array}{l}\text { occlusion of the left vertebral } \\
\text { artery V1-V4 proximal, the } \\
\text { right vertebral artery V1 and } \\
\text { the common carotid artery left }\end{array}$ & No \\
\hline 5 & $\geq 60$ & male & $\begin{array}{l}\text { Left limb } \\
\text { weakness } \\
\text { with } \\
\text { deviated } \\
\text { mouth }\end{array}$ & $\begin{array}{l}\text { right } \\
\text { frontal } \\
\text { parietal } \\
\text { lobe }\end{array}$ & $\begin{array}{l}\text { occlusion of the right vertebral } \\
\text { artery V4 proximal }\end{array}$ & No \\
\hline 6 & $<60$ & male & $\begin{array}{l}\text { Paroxysmal } \\
\text { dizziness } \\
\text { with } \\
\text { bilateral } \\
\text { tinnitus }\end{array}$ & $\begin{array}{l}\text { right } \\
\text { cerebellum, } \\
\text { right } \\
\text { occipital } \\
\text { lobe }\end{array}$ & $\begin{array}{l}\text { severe stenosis of the left } \\
\text { vertebral artery } \mathrm{V} 4 \text { proximal } \\
\text { and right vertebral artery } \mathrm{V} 1\end{array}$ & Yes \\
\hline 7 & $\geq 60$ & male & $\begin{array}{l}\text { Left vision } \\
\text { field loss, } \\
\text { Paroxysmal } \\
\text { dizziness }\end{array}$ & $\begin{array}{l}\text { right } \\
\text { occipital } \\
\text { lobe }\end{array}$ & $\begin{array}{l}\text { occlusion of the left vertebral } \\
\text { artery v1-v4 }\end{array}$ & Yes \\
\hline
\end{tabular}

\section{Discussion}

Previous studies have shown that for one in five patients, cerebral infarction is caused by occlusion of the posterior circulation artery and the V4 segment of the VA is one of the most common locations of posterior circulation artery occlusion $(13,14)$. When occlusion occurred in the V4 segment of the VA, different hemodynamic changes were observed depending on occlusion sites. In occlusions that occurred distal to the PICA exit, the blood flow supplying the cerebellar hemisphere and brainstem was antegrade, as normal (15). However, if the occlusion occurred proximal to the PICA exit, in addition to the collateral circulation between the superior cerebellar artery (SCA) and the PICA (16), retrograde blood flow occurred 
in the segment of the ipsilateral VA distal to the PICA exit, coming from the contralateral VA. As this conforms to the characteristics of "intracerebral steal," we name this phenomenon "V4 segment steal."

Specifically, we define V4 segment steal as: when occlusion in the V4 segment occurs proximally to the PICA exit, the significant blood pressure gradient leads to retrograde blood flow from the contralateral VA through the junction of the vertebral basilar artery to the distal part of the ipsilateral VA. The V4 segment steal develops whenever: a) occlusion of the V4 segment of the VA occurs proximally to the PICA exit; $b$ ) the pathway from the contralateral VA to the ipsilateral PICA is patent; and c) a significant pressure gradient between the contralateral VA and the ipsilateral PICA is present. This retrograde blood flow in the distal part of the ipsilateral VA is visible on DSA.

It has been suggested that the term "vascular steal syndrome" be used only when diversion of flow is accompanied by symptoms of deficient circulation and that "steal phenomenon" or "steal effect" be used when the steal is asymptomatic (17). Common arterial steal syndromes include the subclavian artery steal (18), the vertebrobasilar artery steal and the carotid artery steal (19-21). In our study, two of five cases of new cerebral infarction were contralateral posterior circulation infarction. No obvious arterial stenosis was directly related to the infarction in one patient, and in the other, severe stenosis was present in the V1 segment of the contralateral VA. We hypothesize that the PICA of the ipsilateral VA occlusion stole blood flow from the contralateral VA, resulting in decreased blood flow in the stolen artery, thus leading to the occurrence of clinical ischemic events related to the stolen artery. We refer to this syndrome as blood steal syndrome of the V4 segment of VA. Only one case of acute infarction in the ipsilateral PICA occurred. We speculate that initiation of the V4 segment steal guarantees the blood supply source of the PICA, leading to fewer cerebral infarctions in the lower part of the cerebellar hemisphere of the medulla bulbar, the cerebellar tonsil and other important areas related to PICA $(22,23)$. Due to the small sample size and the use of retrospective analysis, the results of this study are inevitably limited and need to be confirmed through further research.

Our study indicates it is crucial for clinicians treating a patient with a VA occlusion to evaluate whether the occlusion site is located distal or proximal to the PICA exit, and whether the V4 segment steal is in place, since this may affect whether the patient needs further invasive treatment. This knowledge will be helpful when analyzing the clinical symptoms and prognosis of the patient and has important clinical significance.

\section{Conclusion}

There is an underestimated intracerebral collateral circulation pathway when VAOD from the contralateral VA to the Ipsilateral PICA, we name this phenomenon "V4 segment steal."

\section{Abbreviations}


VA: vertebral artery; VAOD: vertebral artery occlusive disease; PICA: posterior inferior cerebellar artery; SCA: superior cerebellar artery; DSA: digital subtraction angiography; MRI: magnetic resonance imaging; DWI: diffusion-weighted imaging

\section{Declarations}

\section{Ethics approval and consent to participate}

This study was approved by the Institutional Review Board of the Sixth Medical Center of PLA General Hospital, (Beijing, 100048, China) and Qiqihar Medical University, (Heilongjiang, 161006, China). Oral informed consent was achieved from each patient through telephone interview.

\section{Consent for publication}

Not applicable.

\section{Availability of data and materials}

The data and images used in the current study are available from the corresponding author upon reasonable request.

\section{Competing interests}

The authors declare that they have no competing interests.

\section{Funding}

This work was supported by 1) New technology and New Business Fund (No. HZXJS [2018]-10) from the Sixth Medical Center, Chinese PLA General Hospital (Formerly known as Navy General Hospital). 2) The National Key R\&D Program of China (2018YFA0108600). 3) Science and technology research project of Heilongjiang Provincial Department of Education (2018-KYYWF-0118). 4) Clinical research fund of Qiqihar Academy of Medical Sciences (QMSI20113). The authors declare that they have no financial relationship with the organization that sponsored the research, and the funding body was not involved in study design, data collection, analysis and writing of the study.

\section{Authors' contributions}

$Y L$ and $Y B$ - study design, data acquisition, interpretations of results, manuscript preparation and revisions; KW, YM, JW and XZ - data acquisition, manuscript revision; CL and FQ - study design, manuscript revision. All authors read and approved the final manuscript

\section{Acknowledgements}

None 


\section{References}

1. Liebeskind DS. Collateral circulation. Stroke. 2003;34(9):2279-84.

2. Raymond SB, Koch MJ, Rabinov JD, Leslie-Mazwi TM, Torok CM, Stapleton CJ, et al. The Role of Collateral Circulation in Branch Vessel Occlusion After Flow Diversion. World Neurosurg. 2018.

3. Reivich M, Holling HE, Roberts B, Toole JF. Reversal of blood flow through the vertebral artery and its effect on cerebral circulation. N Engl J Med. 1961;265:878-85.

4. Bang OY, Goyal M, Liebeskind DS. Collateral Circulation in Ischemic Stroke: Assessment Tools and Therapeutic Strategies. Stroke. 2015;46(11):3302-9.

5. Donahue J, Sumer S, Wintermark M. Assessment of collateral flow in patients with cerebrovascular disorders. J Neuroradiol. 2014;41(4):234-42.

6. Jung S, Wiest R, Gralla J, McKinley R, Mattle H, Liebeskind D. Relevance of the cerebral collateral circulation in ischaemic stroke: time is brain, but collaterals set the pace. Swiss Med Wkly. 2017;147:w14538.

7. Potter BJ, Pinto DS. Subclavian steal syndrome. Circulation. 2014;129(22):2320-3.

8. Maltezos C, Anastasiadou C, Papapetrou A, Galyfos G, Sachmpazidis I, Papacharalampous G. Symptomatic Bilateral Carotid Artery Occlusion: An Uncommon Pattern of Carotid Pathology. Vasc Specialist Int. 2018;34(2):31-4.

9. Wang J, Zheng C, Hou B, Huang A, Zhang X, Du B. Four collateral circulation pathways were observed after common carotid artery occlusion. BMC Neurol. 2019;19(1):201.

10. Nakamura A, Wakugawa Y, Yasaka M, Ogata T, Yasumori K, Kitazono T, et al. Antegrade internal carotid artery collateral flow and cerebral blood flow in patients with common carotid artery occlusion. J Ultrasound Med. 2012;31(10):1561-6.

11. Karlsson L, Kangefjard E, Hermansson S, Stromberg S, Osterberg K, Nordanstig A, et al. Risk of Recurrent Stroke in Patients with Symptomatic Mild (20-49\% NASCET) Carotid Artery Stenosis. Eur J Vasc Endovasc Surg. 2016;52(3):287-94.

12. Kim JS, Nah HW, Park SM, Kim SK, Cho KH, Lee J, et al. Risk factors and stroke mechanisms in atherosclerotic stroke: intracranial compared with extracranial and anterior compared with posterior circulation disease. Stroke. 2012;43(12):3313-8.

13. Gulli G, Marquardt L, Rothwell PM, Markus HS. Stroke risk after posterior circulation stroke/transient ischemic attack and its relationship to site of vertebrobasilar stenosis: pooled data analysis from prospective studies. Stroke. 2013;44(3):598-604.

14. Caplan LR, Wityk RJ, Glass TA, Tapia J, Pazdera L, Chang HM, et al. New England Medical Center Posterior Circulation registry. Ann Neurol. 2004;56(3):389-98.

15. NJ T, TJ S. Research progress of TCD in evaluating hemodynamics of cerebral artery stenosis. Chinese Journal of Urban and Rural Enterprise Hygiene. 2019;34(06):69-72.

16. XW Z, L W. Collateral circulation of severe stenosis or occlusion of intracranial and extracranial arteries. Chin J Geriatr Heart Brain Vessel Dis. 2012;14(11):1231-2. 
17. Lord RS, Adar R, Stein RL. Contribution of the circle of Willis to the subclavian steal syndrome. Circulation. 1969;40(6):871-8.

18. Moccetti F, Brinkert M, Wolfrum M, Toggweiler S. Coronary subclavian steal syndrome. Eur Heart J. 2020;41(13):1345.

19. Kargiotis O, Siahos S, Safouris A, Feleskouras A, Magoufis G, Tsivgoulis G. Subclavian Steal Syndrome with or without Arterial Stenosis: A Review. J Neuroimaging. 2016;26(5):473-80.

20. Osiro S, Zurada A, Gielecki J, Shoja MM, Tubbs RS, Loukas M. A review of subclavian steal syndrome with clinical correlation. Med Sci Monit. 2012;18(5):RA57-63.

21. Kizilkilic O, Oguzkurt L, Tercan F, Yalcin O, Tan M, Yildirim T. Subclavian steal syndrome from the ipsilateral vertebral artery. AJNR Am J Neuroradiol. 2004;25(6):1089-91.

22. Yoon W, Seo JJ, Kim TS, Do HM, Jayaraman MV, Marks MP. Dissection of the V4 segment of the vertebral artery: clinicoradiologic manifestations and endovascular treatment. Eur Radiol. 2007;17(4):983-93.

23. Gaida-Hommernick B, von Smekal U, Kirsch M, Schminke U, Machetanz J, Kessler C. Bilateral cerebellar infarctions caused by a stenosis of a congenitally unpaired posterior inferior cerebellar artery. J Neuroimaging. 2001;11(4):435-7.

\section{Table}

Table 1. The summary of clinical data for the 7 patients of "V4 segment steal" 


\begin{tabular}{|c|c|c|c|c|c|c|}
\hline No. & $\begin{array}{l}\text { Age } \\
\text { ranges }\end{array}$ & gender & phenotype & $\begin{array}{l}\text { infarction } \\
\text { distribution }\end{array}$ & offending vessels & $\begin{array}{l}\text { PICA } \\
\text { steal (or } \\
\text { V4 } \\
\text { segment } \\
\text { steal) } \\
\text { syntrome }\end{array}$ \\
\hline 1 & $<60$ & male & $\begin{array}{l}\text { intermittent } \\
\text { dizziness }\end{array}$ & No & $\begin{array}{l}\text { occlusion of the left vertebral } \\
\text { artery V1 segment, LVA V4 } \\
\text { proximal, left internal carotid } \\
\text { artery, right middle cerebral } \\
\text { artery }\end{array}$ & No \\
\hline 2 & $\geq 60$ & male & $\begin{array}{l}\text { intermittent } \\
\text { dizziness }\end{array}$ & No & $\begin{array}{l}\text { severe stenosis of the right } \\
\text { vertebral artery V1-V4 proximal } \\
\text { and the basilar artery }\end{array}$ & No \\
\hline 3 & $<60$ & male & dizziness & $\begin{array}{l}\text { right } \\
\text { cerebellum }\end{array}$ & $\begin{array}{l}\text { occlusion of the right vertebral } \\
\text { artery } \mathrm{v} 1-\mathrm{v} 4\end{array}$ & No \\
\hline 4 & $\geq 60$ & male & $\begin{array}{l}\text { Paroxysmal } \\
\text { left } \\
\text { amaurosis, } \\
\text { cirop attack }\end{array}$ & $\begin{array}{l}\text { bilateral } \\
\text { frontal } \\
\text { lobe }\end{array}$ & $\begin{array}{l}\text { occlusion of the left vertebral } \\
\text { artery V1- V4 proximal, the right } \\
\text { vertebral artery V1 and the } \\
\text { common carotid artery left }\end{array}$ & No \\
\hline 5 & $\geq 60$ & male & $\begin{array}{l}\text { Left limb } \\
\text { weakness } \\
\text { with } \\
\text { deviated } \\
\text { mouth }\end{array}$ & $\begin{array}{l}\text { right } \\
\text { frontal } \\
\text { parietal } \\
\text { lobe }\end{array}$ & $\begin{array}{l}\text { occlusion of the right vertebral } \\
\text { artery V4 proximal }\end{array}$ & No \\
\hline 6 & $<60$ & male & $\begin{array}{l}\text { Paroxysmal } \\
\text { dizziness } \\
\text { with } \\
\text { bilateral } \\
\text { tinnitus }\end{array}$ & $\begin{array}{l}\text { right } \\
\text { cerebellum, } \\
\text { right } \\
\text { occipital } \\
\text { lobe }\end{array}$ & $\begin{array}{l}\text { severe stenosis of the left } \\
\text { vertebral artery V4 proximal } \\
\text { and right vertebral artery V1 }\end{array}$ & Yes \\
\hline 7 & $\geq 60$ & male & $\begin{array}{l}\text { Left vision } \\
\text { field loss, } \\
\text { Paroxysmal } \\
\text { dizziness }\end{array}$ & $\begin{array}{l}\text { right } \\
\text { occipital } \\
\text { lobe }\end{array}$ & $\begin{array}{l}\text { occlusion of the left vertebral } \\
\text { artery v1-v4 }\end{array}$ & Yes \\
\hline
\end{tabular}

\section{Figures}



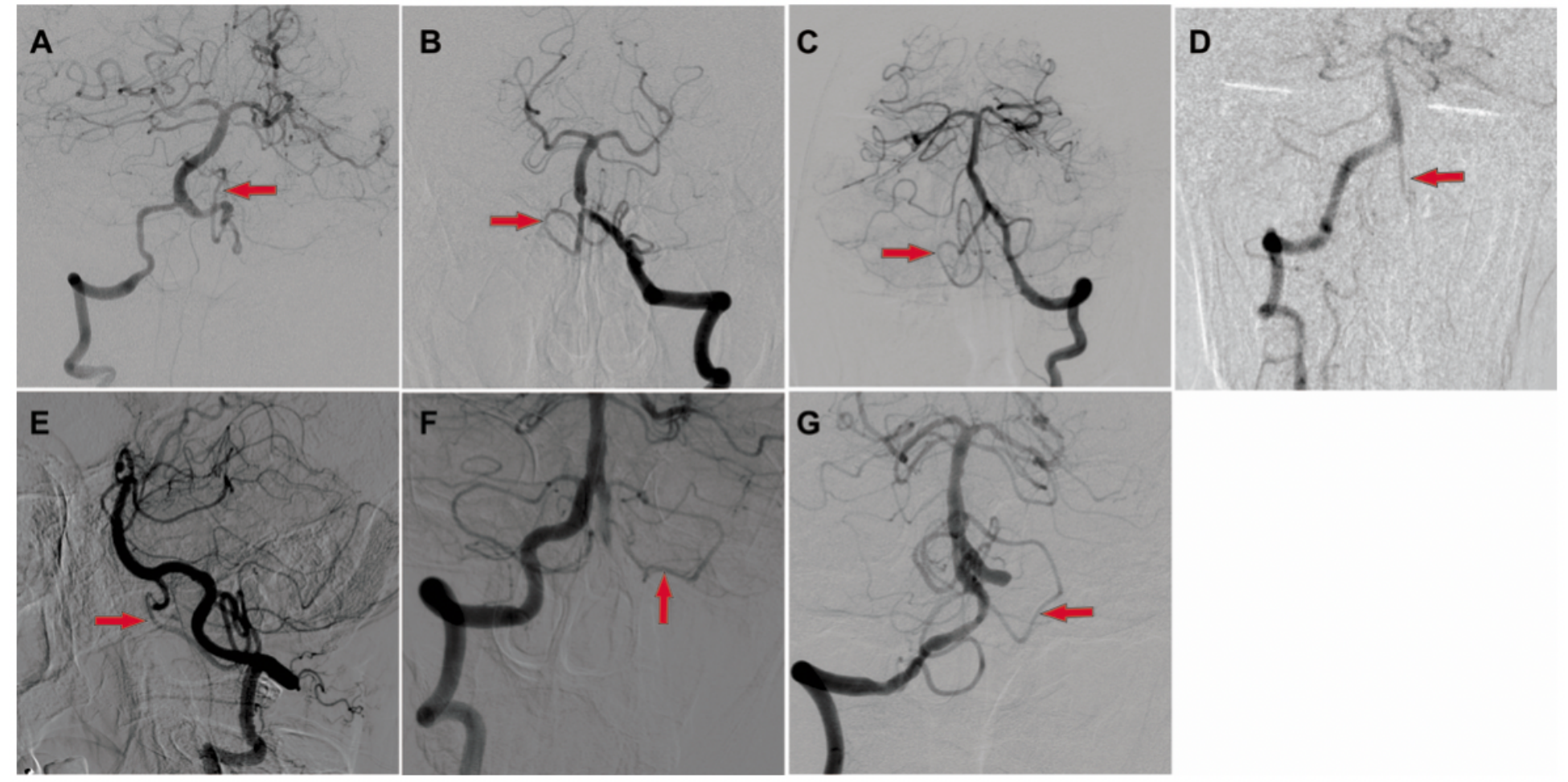

\section{Figure 1}

The DSA of the contralateral VA shows the V4 segment steal. A-G represent patient1-7, respectively. The arrow indicates the PICA. 


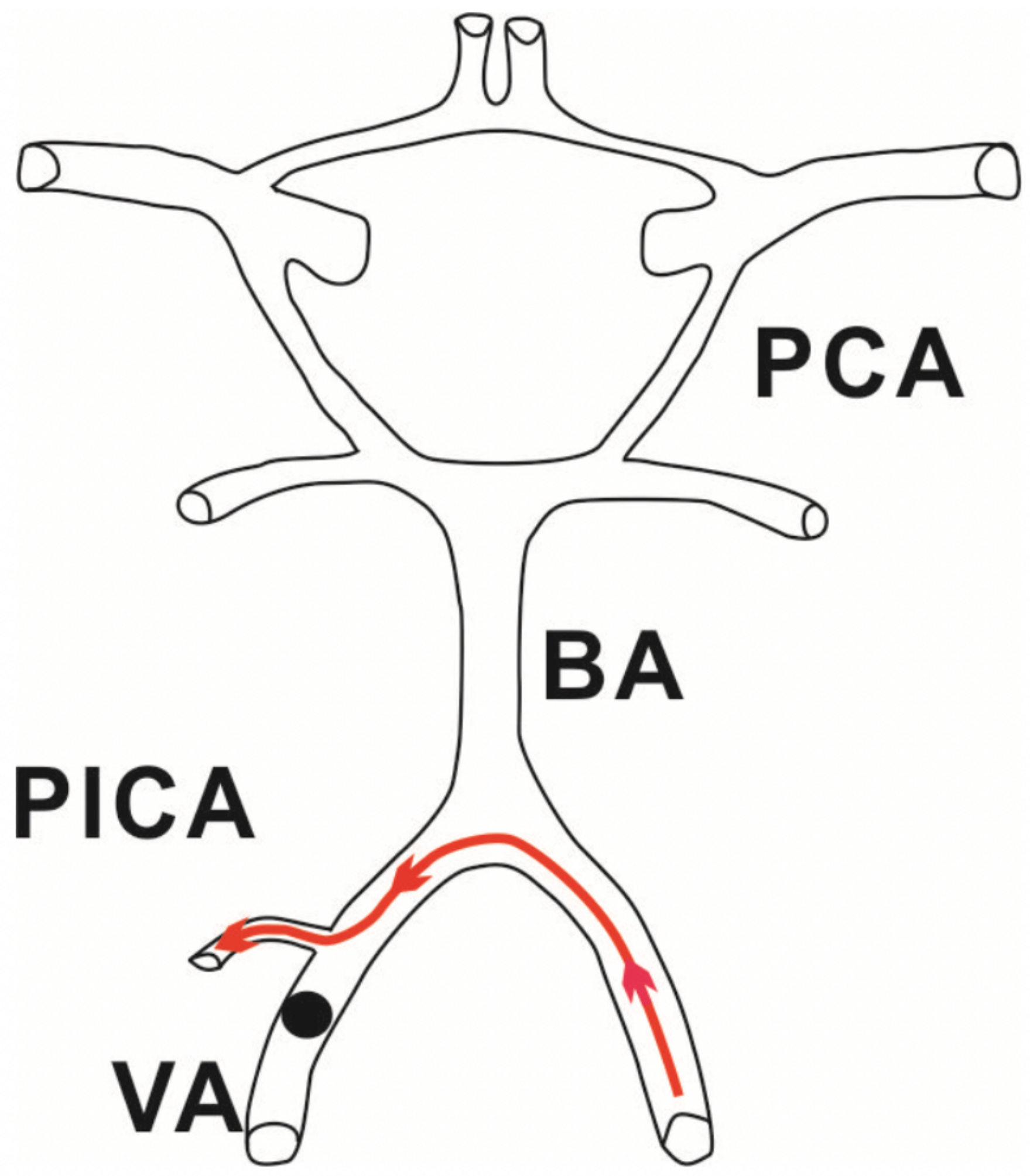

Figure 2

The DSA of the contralateral VA shows the V4 segment steal. A-G represent patient1-7, respectively. The arrow indicates the PICA. 


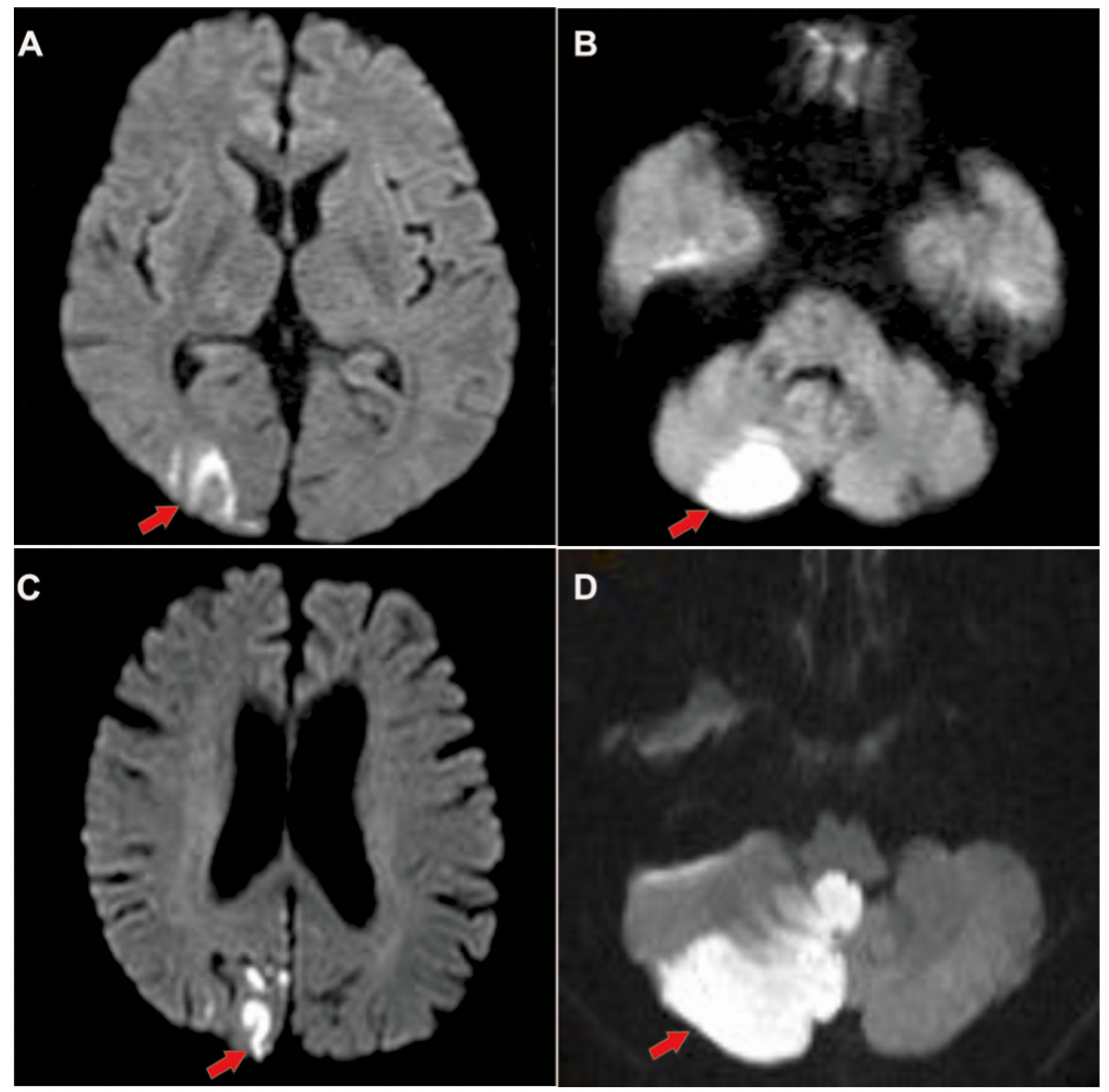

\section{Figure 3}

DWI shows the acute infarctions of case 6 in the right cerebellum and right occipital lobe (A, B, red arrow), of case 7 in the right occipital lobe (C, red arrow), of case 3 in the right cerebellum (D, red arrow). 